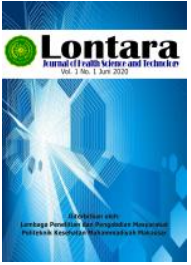

http://jurnal.poltekkesmu.online/lontarariset

Vol 2, No. 2, Desember 2021, pp 89-95

p-ISSN:0000-0000 dan e-ISSN: 2721-6179

DOI: $\underline{\text { https://doi.org/10.53861/lontarariset.v2i2 }}$

\title{
KUALITAS LIMBAH CAIR INDUSTRI TAHU BERDASARKAN PARAMETER BOD, pH, COD, DAN TSS DI KELURAHAN BARA-BARAYA TIMUR KOTA MAKASSAR
}

\author{
Novi Poni Harwani, Sartika Fathir Rahman, Siti Maifa Diapati \\ Sanitasi, Politeknik Kesehatan Muhammadiyah Makassar, Indonesia \\ Teknik Lingkungan, Sekolah Tinggi Teknologi Nusantara Indonesia, Indonesia \\ Email:noviponikero@gmail.com
}

\section{Artikel info}

\section{Artikel history:}

Received; 03-09-2021

Revised: 22-10-2021

Accepted; 24-11-2021

Keyword:

Tofu, Wastewater, TSS, $p H, B O D, C O D$

Kata Kunci:

Tahu, Limbah Cair, TSS, $\mathrm{pH}, \mathrm{BOD}, \mathrm{COD}$

\begin{abstract}
Tofu industrial liquid waste contains high organic matter, if it is discharged into the environment without being processed first, it will have a negative impact in the form of environmental pollution. Currently, most of the tofu industry is still a small household scale industry, for example in Bara-baraya one of the tofu industries is not equipped with a wastewater treatment unit. The Bara-baraya tofu industry is located right in the middle of a residential area, so this can cause disturbance to the surrounding environment. This study aims to determine the quality of the tofu industrial wastewater in the Bara-Baraya Timur Village, Makassar City in terms of $p H, B O D$, $C O D$, and TSS parameters. The type of research used is observational research with a descriptive approach. The method of examining samples from the parameters of BOD, COD, TSS and pH in the tofu industrial wastewater refers to the SNI for water quality testing methods and is examined at the Makassar Health Laboratory Center. The results of the inspection of the quality of tofu waste water compared to the Minister of Environment Regulation No. 5/2014 are the $\mathrm{pH}$ parameter 3.85 (not eligible), COD parameter $499 \mathrm{mg} / \mathrm{L}$ (not eligible), TSS parameter $4.777 .50 \mathrm{mg} / \mathrm{L}$ (not eligible), and BOD parameters $1.771 .88 \mathrm{mg} / \mathrm{L}$ (not eligible). The conclusion in this study is the quality of tofu wastewater in waste samples that have not undergone treatment at the wastewater treatment plant (IPAL) located in the tofu industry located in RW 4, Bara-Baraya Village, Makassar City, does not meet the requirements and exceeds the quality standards that have been set. determined by the government so that it can cause pollution to the surrounding environment.
\end{abstract}

Abstrak. Limbah cair industri tahu mengandung bahan organik yang tinggi, bila dibuang ke lingkungan tanpa diolah terlebih dahulu akan menimbulkan dampak negatif berupa pencemaran lingkungan. Pada saat ini sebagian besar industri tahu masih merupakan industri kecil skala rumah tangga, seperti misalnya di Bara-baraya salah salah satu industri tahu tidak dilengkapi dengan unit pengolahan air limbah. Industri tahu Bara-baraya terletak persis di tengah pemukiman warga sehingga hal ini dapat menyebabkan gangguan bagi lingkungan sekitar. Penelitian ini bertujuan untuk mengetahui kualitas air limbah industri tahu di Kelurahan Bara-Baraya Timur Kota Makassar ditinjau 
dari parameter $\mathrm{pH}, \mathrm{BOD}, \mathrm{COD}$, dan TSS. Jenis penelitian yang digunakan adalah penelitian observasional dengan pendekatan deskriptif. Metode pemeriksaan sampel dari parameter BOD, COD, TSS dan pH pada air limbah industri tahu ini merujuk pada SNI metode pengujian kualitas air dan diperiksa di Balai Besar Laboratorium Kesehatan Makassar. Hasil pemeriksaan Kualitas air limbah tahu yang dibandingkan dengan Peraturan Menteri LH No 5 Tahun 2014 yaitu parameter pH 3,85 (tidak memenuhi syarat), parameter COD $499 \mathrm{mg} / \mathrm{L}$ (tidak memenuhi syarat), parameter TSS 4.777,50 $\mathrm{mg} / \mathrm{L}$ (tidak memenuhi syarat), dan parameter BOD $1.771,88 \mathrm{mg} / \mathrm{L}$ (tidak memenuhi syarat). Kesimpulan dalam penelitian ini adalah Kualitas air limbah tahu pada sampel limbah yang tidak mengalami proses pengolahan di instalasi pengolahan air limbah (IPAL) yang berada pada Industri tahu yang berada di RW 4 Kelurahan Bara-Baraya Kota Makassar tidak memenuhi syarat dan melebihi baku mutu yang telah ditetapkan oleh pemerintah sehingga dapat menyebabkan pencemaran pada lingkungan sekitar.

Coresponden author:

Email: noviponikero@gmail.com

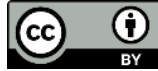

artikel dengan akses terbuka dibawah lisensi CC BY -4.0

\section{PENDAHULUAN}

Permasalahan Lingkungan Hidup sampai saat ini masih menjadi bahan kajian yang tiada hentinya dibicarakan. Upaya pengendalian dampak lingkungan hidup sebagai akibat dari kerusakan/pencemaran sistem ekologi memerlukan perhatian yang khusus. Lingkungan yang bersih dan sehat merupakan kebutuhan hidup yang tidak bisa diabaikan. Karena hal ini menyangkut hubungan anatara manusia dan lingkungan sekitarnya (H. J. Mukono, 2008). Terjadinya penurunan kualitas lingkungan hidup merupakan isu yang memerlukan perhatian dari berbagai pihak. Terutama di daerah perkotaan dimana pertumbuhan jumlah penduduk yang berimplikasi terhadap eksploitasi daerah aliran sungai secara tidak terkendali.

Kegiatan pembangunan dengan berbagai aktivitas penduduk ini mempunyai pengaruh langsung terhadap daya dukung lingkungan sehingga terjadi pergeseran keseimbangan lingkungan dan pemanfaatan sumber daya alam yang tidak profesional dan tidak efisien, serta kurangnya tingkat kesadaran masyarakat dan perusahaan sebagai sektor swasta dalam program pengelolaan lingkungan hidup, sehingga menimbulkan permasalahan lingkungan hidup yang cukup serius. Saat ini, usaha tahu di indonesia rata-rata masih dilakukan dengan teknologi yang sederhana, sehingga tingkat efisiensi penggunaan sumber daya (air dan bahan baku) dirasakan masih rendah dan tingkat produksi limbahnya juga relatif tinggi. Kegiatan industri tahu di Indonesia didominasi oleh usaha-usaha skala kecil dengan modal yang terbatas. Dari segi lokasi, usaha ini juga sangat tersebar di seluruh wilayah Indonesia. Sumber daya manusia yang terlibat pada umumnya bertaraf pendidikan yang relatif rendah, serta belum banyak yang melakukan pengolahan limbah. 
Kualitas Limbah Cair Industri Tahu Berdasarkan Parameter BOD, pH, COD, dan TSS

Di Kelurahan Bara-Baraya Timur Kota Makassar

(Novi Poni Harwani, Sartika Fathir Rahman, Siti Maifa Diapati)

Industri tahu dalam proses pengolahannya menghasilkan limbah, baik limbah padat maupun cair. Limbah padat dihasilkan dari proses penyaringan dan penggumpalan, limbah ini kebanyakan oleh pengrajin dijual dan diolah menjadi tempe gembus, kerupuk ampas tahu, pakan ternak, dan diolah menjadi tepung ampas tahu yang akan dijadikan bahan dasar pembuatan roti kering dan cake. Sedangkan limbah cairnya dihasilkan dari proses pencucian, perebusan, pengepresan, dan pencetakan tahu, oleh karena itu limbah cair yang dihasilkan sangat tinggi. Limbah cair tahu dengan karakteristik mengandung bahan organik tinggi dan kadar BOD, COD, yang cukup tinggi pula, jika langsung dibuang ke badan air, jelas sekali akan menurunkan daya dukung lingkungan. Sehingga industri tahu memerlukan suatu pengolahan limbah yang bertujuan untuk mengurangi resiko beban pencemaran yang ada. Limbah cair industri tahu mengandung bahan organik yang tinggi, bila dibuang ke lingkungan tanpa diolah terlebih dahulu akan menimbulkan dampak negatif berupa pencemaran di lingkungan industri. Pada saat ini sebagian besar industri tahu masih merupakan industri kecil skala rumah tangga, seperti misalnya di Bara-baraya salah salah satu industri tahu tidak dilengkapi dengan unit pengolahan air limbah sehingga dapat menyebabkan pencemaran lingkungan sekitar industri. Industri tahu Bara-baraya terletak persis di tengah pemukiman warga. Sehingga hal ini dapat menyebabkan gangguan bagi warga apa lagi saat ini lokasi tersebut sudah mengalami gangguan estetika. Tujuan penelitian untuk mengetahui kualitas air limbah industri tahu di Kelurahan BaraBaraya Timur Kota Makassar ditinjau dari parameter pH, BOD (Biologi Oxygen Demand), COD (Chemical Oxygen Demand), dan TSS.

\section{BAHAN DAN METODE}

Metode penelitian yang digunakan adalah penelitian observasional dengan pendekatan deskriptif yaitu dengan mengumpulkan data dari hasil pemeriksaan laboratorium kemudian dibandingkan dengan standar baku mutu air limbah. Metode pemeriksaan sampel dari parameter BOD, COD, TSS dan pH pada air limbah industri tahu ini merujuk pada SNI metode pengujian kualitas air dan diperiksa di Balai Besar Laboratorium Kesehatan Makassar. Lokasi penelitian ini terletak di jalan Abubakar Lambogo Kelurahan Bara-Baraya Timur Kota Makassar, dimana industri tahu yang akan dijadikan tempat penelitian adalah industri tahu dengan hasil produksi terbesar yaitu dengan produksi $\pm 250 \mathrm{~kg} / \mathrm{hari}$ yang menghasilkan limbah ke badan air (di kanal) serta terletak di tengah pemukiman penduduk yang padat.

\section{HASIL PENELITIAN}

Pengambilan sampel dilakukan hanya pada satu titik yaitu di RW 4 Kelurahan Bara-baraya Kota Makassar, pengambilan sampelnya dilakukan dalam satu hari. Hasil pemeriksaan Kualitas air limbah tahu dengan beberapa parameter yang dibandingkan dengan Peraturan Menteri LH No 5 Tahun 2014 Mengenai Standar Baku Mutu Air Limbah. Hasil pemeriksaan laboratorium menunjukkan hasil 
sebagai berikut: hasil pengujian parameter $\mathrm{pH}$ 3,85 dibawah dari batas maksimum yang diperbolehkan (tidak memenuhi syarat), untuk hasil pengujian parameter COD mendapatkan hasil $499 \mathrm{mg} / \mathrm{L}$ (tidak memenuhi syarat), untuk parameter TSS mendapatkan hasil $4.777,50 \mathrm{mg} / \mathrm{L}$ yaitu diatas batas maksimum yang diperbolehkan (Tidak memenuhi syarat). Sedangkan untuk parameter BOD hasil pengujian yaitu $1.771,88 \mathrm{mg} / \mathrm{L}$ diatas dari batas maksimun yang diperbolehkan (Tidak memenuhi syarat).

Tabel 1. Baku mutu air limbah usaha dan/atau kegiatan pengolahan kedelai tahu

\begin{tabular}{lccc}
\hline Parameter & Satuan & Kadar $(\mathrm{Mg} / \mathrm{L})$ & Beban $(\mathrm{kg} /$ ton $)$ \\
\hline pH & - & $6-9$ & \\
BOD & $\mathrm{Mg} / \mathrm{l}$ & $\mathbf{1 5 0}$ & $\mathbf{3}$ \\
\hline COD & $\mathrm{Mg} / \mathrm{l}$ & $\mathbf{3 0 0}$ & $\mathbf{6}$ \\
\hline TSS & $\mathrm{Mg} / \mathrm{l}$ & $\mathbf{2 0 0}$ & 4 \\
\hline
\end{tabular}

Tabel 2. Standar Baku Mutu Air Limbah Domestik Menurut Permen LH no 5 Tahun 2014

\begin{tabular}{lcc}
\hline Parameter & Satuan & Kadar maksimum \\
\hline pH & - & $\mathbf{6 - 9}$ \\
\hline BOD & $\mathrm{Mg} / \mathrm{l}$ & $\mathbf{3 0}$ \\
\hline COD & $\mathrm{Mg} / \mathrm{l}$ & $\mathbf{1 0 0}$ \\
\hline TSS & $\mathrm{Mg} / \mathrm{l}$ & $\mathbf{3 0}$ \\
\hline
\end{tabular}

\section{PEMBAHASAN}

Setiap usaha dan/atau kegiatan yang menghasilkan air limbah domestik wajib melakukan pengolahan air limbah domestik yang dihasilkannya. Setiap usaha dan/atau kegiatan pengolahan air limbah domestik, wajib memiliki prosedur operasional standar pengolahan air limbah domestik dan sistem tangga darurat. Baku mutu air limbah adalah ukuran batas atau kadar unsur pencemar dan atau jumlah unsur pencemar yang ditenggang keberadaannya dalam air limbah yang akan dibuang atau dilepas ke dalam sumber air dari suatu usaha dan atau kegiatan. (PermenLH, 2014).

1. Parameter $\mathrm{pH}$

Hasil pemeriksaan Kualitas air limbah tahu dilihat dari hasil pengujian parameter $\mathrm{pH} 3,85$ dibawah dari batas minimum 6-9 yang diperbolehkan (tidak memenuhi syarat). Nilai pH tersebut menunjukkan bahwa limbah cair tanpa pengolahan bersifat asam. Menurut penelitian Darajatin Diwani Kesuma (2013), menunjukkan bahwa dari 4 sampel penelitian hanya ada 1 sampel yang menunjukkan bahwa nilai $\mathrm{pH}$ berada dibawah batas minimum yaitu 3,8 sedangkan 3 sampel lainnya menunjukkan berada pada nilai $\mathrm{pH}$ 6-8. Hal ini menunjukkan nilai $\mathrm{pH}$ 3,8 tersebut bersifat asam dan dapat menyebabkan pencemaran terhadap badan air. Selain itu penelitian yang dilakukan oleh Richa Diari Sandi (2019) menunjukkan hasil yang sama yaitu pada 2 lokasi penelitiannya menunjukkan kandungan $\mathrm{pH}$ dibawah nilai minumum 6 yang menandakan air tersebut bersifat asam. Sifat air yang sangat asam tidak dianjurkan dalam golongan apapun. Air yang mengandung nilai $\mathrm{pH}$ 6.7-8.6 merupakan syarat yang mendukung pertumbuhan dan perkembangbiakan populasi ikan (Sastrawijaya, 
Kualitas Limbah Cair Industri Tahu Berdasarkan Parameter BOD, pH, COD, dan TSS

Di Kelurahan Bara-Baraya Timur Kota Makassar

(Novi Poni Harwani, Sartika Fathir Rahman, Siti Maifa Diapati)

1991). Hal ini sejalan dengan penelitian terdahulu oleh Suryo Yonathan dkk (2021) dengan hasil pH 2,65 sehingga perlu adanya proses pengolahan yang mampu menstabilkan nilai $\mathrm{pH}$ pada limbah air tahu yang akan dibuang ke badan air yang dapt menyebabkan penurunan oksigen terlarut dalam air.

2. Parameter COD

Hasil penelitian ini menunjukkan kadar COD tidak memenuhi persyaratan baku mutu air limbah domestik (100 mg/L) dan baku mutu air limbah industri tahu $(300 \mathrm{mg} / \mathrm{L})$ dengan hasil uji 4.777,50 mg/L. Hal ini menunjukkan bahwa tingkat kebutuhan akan oksigen dalam air sangat tinggi dari batas maksimum yang dipersyaratkan. Semakin tinggi konsentrasi COD dalam suatu perairan maka menunjukkan tingginya konsentrasi bahan organik di dalam air. (Sepriani dkk, 2016). Penelitian ini sejalan dengan yang dilakukan oleh Suryo Yonathan dkk (2021) dan Darajatin Diwani Kesuma (2013) dengan hasil yang menunjukkan 4 sampel diuji kadar COD-nya dan mendapatkan hasil diatas 300mg/L. Nilai COD yang sangat tinggi dalam air limbah berasal dari senyawa organik dalam limbah tahu yang sulit diuraikan oleh mikroorganisme. Perairan yang memiliki kadar COD yang tinggi tidak dianjurkan untuk kepentingan perikanan, perairan dan pertanian. Salah satu penelitian yang dilakukan oleh PUSTEKLIM menunjukkan bahwa konsentrasi bahan-bahan organik seperti COD didalam limbah cair industri tahu cukup tinggi yakni berkisar antara 4000-12.000 ppm. (Sudjarwo dan Tanaka, 2014). Beban pencemaran yang tinggi pada suatu badan air akan menyebabkan penurunan kualitas air. Kualitas air yang menurun akan memberikan dampak yang buruk bagi ekosistem air. (Diari Richa, 2019). Upaya yang dapat dilakukan dalam meminimalkan resiko yang dapat ditimbulkan dari limbah cair industri tahu tersebut dengan cara mengolah terlebih dahulu limbah cair tahu sebelum dibuang ke lingkungan melalui Instalasi pengolahan air limbah (IPAL).

\section{Parameter BOD}

Hasil pengujian air limbah tahu pada penelitian ini menunjukkan kadar BOD 1.771,88 mg/L hal ini melebihi batas baku mutu maksimum yang dipersyaratkan menurut Peraturan Menteri LH no 5 tahun 2014 yaitu 150 Mg/L. Penelitian Darajatin Diwani Kesuma (2013) juga menunjukkan hasil yang sama dengan 3 Sampel menunjukan kadar BOD yang tinggi diatas maksimum namun ada 1 sampel yang memiliki kadar BOD dibawah baku mutu yang dipersyaratkan. Besarnya nilai BOD pada sampel air limbah tahu diakibatkan oleh tingginya protein yang merupakan zat organik yang terkandung dalam limbah tahu sehingga membutuhkan oksigen terlarut untuk dekomposisi. Sejalan dengan penelitian ini, hasil dari penelitian Suryo Yonathan dkk (2021) menunjukkan kadar BOD $2.290 \mathrm{Mg} / \mathrm{L}$ merupakan angka yang tinggi sehingga diperlukan pengolahan air limbah sebelum dibuang ke badan air. Tingginya kandungan zat organik pada air menyebabkan kebutuhan oksigen oleh bakteri bertambah pula, akibatnya kebutuhan oksigen dalam air (BOD) akan meningkat dan jumlah kandungan terlarut (DO) menurun sehingga kehidupan dalam air akan terganggu (Mulia, 2005). 


\section{Parameter TSS}

Hasil penelitian ini menunjukkan kadar TSS air limbah tahu adalah $499 \mathrm{mg} / \mathrm{l}$ jauh diatas baku mutu air limbah domestik (30 mg/l) dan baku mutu air limbah tahu $(200 \mathrm{mg} / \mathrm{l})$. Hasil ini sejalan dengan penelitian Darajatin Diwani Kesuma dan M. Widyastuti (2013) yang menunjukkan salah satu dari 4 sampel pemeriksaan TSS pada air limbah tahu ditemukan nilai diatas baku mutu yang dipersyaratkan sedangkan 3 lainnya masih memenuhi baku mutu yang dipersyaratkan. Penelitian ini tidak sejalan dengan penelitian terdahulu oleh Ariyeti, dkk. (2020) dimana hasil penelitian yang dilakukan mendapatkan kadar TSS kurang dari $200 \mathrm{mg} / \mathrm{l}$ yang masih dibawah baku mutu air limbah industri menurut Peraturan Menteri LH No. 5 tahun 2014. Hal yang sama juga ditemukan pada penelitian Richa Diari Sandi bahwa kadar TSS yang terdapat pada air limbah tersebut tidak melebihi batas baku mutu yang dipersyaratkan. Selain itu Penelitian Febrian Sayow dkk (2020) juga mendapatkan hal yang sama bahwa hasil kadar TSS masih berada pada kadar normal dan belum melewati baku mutu air limbah yang ditetapkan. Ini karena sudah dipasang alat penyaring sehinggga padatan-padatan hasil pembuatan tahu dan tempe tertahan pada alat penyaring tersebut.

\section{KESIMPULAN}

Kesimpulan penelitian ini bahwa Kualitas air limbah tahu pada sampel limbah yang tidak mengalami proses pengolahan di instalasi pengolahan air limbah (IPAL) pada industri tahu di RW 4 Kelurahan Bara-Baraya Kota Makassar tidak memenuhi syarat dan melebihi baku mutu yang telah ditetapkan oleh pemerintah sehingga dapat menyebabkan pencemaran pada lingkungan sekitar. Beban pencemar yang tinggi memberi pengaruh terhadap kualitas air. Kualitas air yang menurun akan berdampak buruk bagi ekosistem air.

\section{SARAN}

Disarankan agar dapat melakukan pengolahan air limbah tahu pada instalaasi pengolahan air limbah (IPAL) sebelum dibuang langsung ke sungai atau badan air dan perlu dilakukan penelitian lanjutan tentang kualitas air limbah tahu pada lokasi tersebut agar dapat mengatasi masalah pencemaran yang diakibatkan.

\section{UCAPAN TERIMA KASIH}

Ucapan terima kasih penulis kepada Direktur yang telah memberikan izin penelitian, dan seluruh civitas akademika prodi Sanitasi Politeknik Kesehatan Muhammadiyah Makassar yang telah memberikan bantuan atas seluruh rangkaian penyelesaian penelitian.

\section{DAFTAR PUSTAKA}

Alaerts, G dan Santika. 1987. Metode Penelitian Air. Usaha Nasional. Surabaya. 
Kualitas Limbah Cair Industri Tahu Berdasarkan Parameter BOD, pH, COD, dan TSS

Di Kelurahan Bara-Baraya Timur Kota Makassar

(Novi Poni Harwani, Sartika Fathir Rahman, Siti Maifa Diapati)

Amonia. Wikipedia: Ensiklopedia Gratis. Wikipedia, Ensiklopedia Gratis, 28 Juni 2021. Web. 03 Agustus 2021. id.wikipedia.org/wiki/Amonia.

Ariyetti, A., Anggia, M., \& Wijayanti, R. (2020). Analisa Kualitas Air Limbah Tahu Di Kecamatan Nanggalo Kota Padang. Jurnal Katalisator, 5(1), 74-80.

Adibroto, T. (1997). Teknologi Pengolahan Limbah Tahu Tempe Dengan Proses Biofilter AnaerobAerob. Kelompok Teknologi Pengolahan Air Bersih dan Limbah Cair. BPPT. Jakarta Pusat.

Kesuma, D. D., \& Widyastuti, M. (2013). Pengaruh Limbah Industri Tahu Terhadap Kualitas Air Sungai Di Kabupaten Klaten. Jurnal Bumi Indonesia, 2(1).

Darmono. (2006). Lingkungan hidup dan pencemaran: hubungannya dengan toksikologi senyawa logam. Universitas Indonesia.

Daud, A. Anwar. 2005, Dasar-Dasar Kesehatan Lingkungan. Makassar: Hasanuddin University Press (LEPHAS).

Sani, E. Y. (2006). Pengolahan air limbah tahu menggunakan Reaktor anaerob bersekat dan aerob (Doctoral dissertation, program Pascasarjana Universitas Diponegoro).

H. J. Mukono. 2008. Prinsip Dasar Kesehatan Lingkungan Edisi 2 Surabaya

Hayat, A. F. (2019). Pemanfaatan Biji Kelor (Moringa oleifera) Sebagai Koagulan Dalam Menurunkan Kadar Amoniak (NH3) pada Air Limbah Rumah Sakit. Celebes Health Journal, $1(2), 91-98$.

Jenie, B. S. L., Jenie, B. S. L., \& Rahayu, W. P. (1993). Penanganan limbah industri pangan. Kanisius.

Kaswinarni, F. (2008). Kajian Teknis Pengolahan Limbah Padat dan Cair Industri Tahu. Majalah Lontar, 22(2).

Sandi, R. D., \& Hariyanto, B. (2019). Analisis Kualitas Air Dan Distribusi Limbah Cair Industri Tahu Di Sungai Murong Kecamatan Jogoroto Kabupaten Jombang. Swara Bhumi, 1(2).

Sudjarwo, H., \& Tanaka, N. (2014). Manual Teknologi Tepat Guna Pengolahan Air Limbah. PUSTEKLIM: Yogyakarta.

Pambudi, Y. S., Sudaryantiningsih, C., \& Geraldita, G. (2021). Analisis Karakteristik Air Limbah Industri Tahu dan Alternatif Proses Pengolahannya Berdasarkan Prinsip-Prinsip Teknologi Tepat Guna. Syntax Literate; Jurnal Ilmiah Indonesia, 6(8), 4180-4192. 